\title{
sciendo
}

Current Issues in Pharmacy and Medical Sciences

Formerly ANNALES UNIVERSITATIS MARIAE CURIE-SKLODOWSKA, SECTIO DDD, PHARMACIA

\section{Microbiological evaluation of 10 commercial probiotic products available in Poland}

\author{
Izabela Korona-GlowniaK ${ }^{1 *}{ }^{\circledR}$, Radoslaw SiwieC $^{1}$, Iwona LuszczewsKa-Sierakowska ${ }^{2}$, \\ RysZard MaCiejeWSKI ${ }^{2}$, RAFAl Wrobel ${ }^{3}$, ANNA MALM ${ }^{1}$
}

\author{
${ }^{1}$ Department of Pharmaceutical Microbiology with Laboratory for Microbiological Diagnostics, Medical University of Lublin, Poland \\ 2 Department of Human Anatomy, Medical University of Lublin, Poland \\ ${ }^{3}$ Department of Paediatric Dentistry, Medical University of Lublin, Poland
}

\begin{tabular}{|c|c|}
\hline ARTICLE INFO & ABSTRACT \\
\hline $\begin{array}{l}\text { Received } 20 \text { November } 2018 \\
\text { Accepted } 03 \text { January } 2019\end{array}$ & \multirow{2}{*}{$\begin{array}{l}\text { The aim of this study was to analyze the quality of } 10 \text { commonly available commercial } \\
\text { probiotic products used in Poland. These items were tested for the total viable bacterial } \\
\text { count, and for identifying the isolated strains. This was performed using the Polymerase } \\
\text { Chain Reaction method. The results showed that five of the tested products had not the } \\
\text { applicable number of viable bacteria declared by manufacturer. Moreover, not all declared } \\
\text { probiotic strains were found in three of the tested products during analyses. It is clear } \\
\text { that a regular control of probiotic products needs be introduced that can guarantee its } \\
\text { beneficial properties. }\end{array}$} \\
\hline $\begin{array}{l}\text { Keywords: } \\
\text { probiotics, } \\
\text { viable bacterial count, } \\
\text { lactobacilli, } \\
\text { bifidobacteria. }\end{array}$ & \\
\hline
\end{tabular}

\section{INTRODUCTION}

In recent years, global interest has significantly increased in the use of functional foods containing probiotic bacteria for health promotion and disease prevention. According to the Food and Agriculture Organization of the United Nations and World Health Organization (FAO/WHO, 2001), probiotics are "live microorganisms which when administered in adequate amounts confer a health benefit on the host" [1]. Bacterial strains, commonly used as probiotics belong to genera Lactobacillus spp. and Bifidobacterium spp. Scientific evidences for benefits from probiotics for human involves alleviations of the symptoms of lactose intolerance [2] and reduction of the duration of acute infectious gastroenteritidis in children [3]. Some other benefits include improving of the condition of the intestinal tract (traveler's and antibiotic-associated diarrhea), a decreasing prevalence of vaginal infections, an increasing immune function and a decrease of the cholesterol and lipid levels [1,4,5]. Daily intake of at least $10^{7}-10^{9}$ viable colony-forming units (CFU) per day is necessary to obtain a sufficient colonization of the gut [6].

The regulatory status of probiotics is currently not established on an international basis, however, in Europe, probiotic foods and food supplements are covered by the Food Products Directive and Regulation (regulation 178/2002/

\footnotetext{
* Corresponding author

e-mail: iza.glowniak@umlub.pl
}

EC; directive 2000/13/EU). According to the FAO/WHO document, "there is a need to accurately enumerate the probiotic bacteria in food products in order to include them on the label. The label should state the viable concentration of each probiotic present at the end of shelf-life" [1]. Previous studies regarding the evaluation of probiotic products all over the world detected a widespread lack of correlation between the label and the actual content of probiotic products $[7,8]$.

In Poland, there is no national governmental agency responsible for verifying the quality of dietary supplements or food for special medical purposes (FSMP). This means less control over them and the actuality of these products may not comply with the information accompanying the product. The aim of this study was to analyze 10 probiotic products commonly used in Poland with regards to quantity and quality of included probiotic strains.

\section{MATERIAL AND METHODS}

A total of 10 commercial probiotic-based products available in Poland as of 2016 were included in the study. Three different packages of each batch of product were collected in random locations. Three different types of products were analyzed: 8 containing capsules, 1 - powder and 1 - tablets. The shelf-life of the products was listed as 2 years and none of the products had exceeded the expiration date. 


\section{Bacteria count}

For isolation of lactobacilli, De Man Rogosa and Sharpe agar (MRs agar) was used. Herein, bifidobacteria and streptococci were evaluated on Schaedler agar supplemented with $5 \%$ sheep blood. Capsules of each probiotic were suspended in $10 \mathrm{~mL}$ of sterile peptone water, since lyophilized products were not easily dissolved, suspensions were allowed to stabilize for 20 minutes. Serial 10-fold dilutions were prepared and $0.1 \mathrm{ml}$ of each dilution was plated on all media. The plates were incubated for $48 \mathrm{~h}$ at $37^{\circ} \mathrm{C}$ in anaerobic conditions (using a GENbag anaer from bioMérieux). The counting of colonies of each plate was performed by colony count reader (Interscience Scan 1200). The bacterial count was expressed as CFU per dose. Each product was tested twice and the mean counts of three packages were evaluated.

\section{Bacterial identification}

Bacteria were preliminarily identified on the basis of colony morphology (shape, appearance and size) and Gram staining. Different colonies were picked and purified using the incubation conditions described above. Final identification was carried out by PCR reaction. DNA isolation was performed using Genomic Mini AX BACTERIA (A\&A Biotechnology). Multiplex or single PCR reactions were performed with the use of the REDTaq ReadyMix PCR Reaction Mix (Sigma-Aldrich), followed by electrophoresis in 1,5\% agarose gel. Primers and conditions used for the reactions were described previously $[9,10]$. The detection level of the microorganisms was $10^{4} \mathrm{CFU} /$ dose.

\section{RESULTS}

A total of 5 dietary supplements, 3 FSMP and 2 medicinal products, from two or three different batches, available on the market as of 2016 were tested (Table 1). Our evaluation of 10 products available in Poland showed that only 4 products were in accordance with package claims in level of quantity. These products contained the declared amount of all the claimed species. They were: Osłonka normal containing L. rhamnosus, L. plantarum, Bifidobacterium lactis in $10^{9} \mathrm{CFU} /$ dose; Dicoflor containing $L$. rhamnosus in $10^{9} \mathrm{CFU} / \mathrm{ml}$, Lacidofil containing L. rhamnosus, L. helveticus in $10^{9} \mathrm{CFU} /$ dose and BioGaia Protectis containing L.reuteri in $10^{8} \mathrm{CFU} /$ dose. The remaining products were not in agreement with their labels in aspect of viable amount of bacteria. They had bacterial counts that were less than a tenth of those stated (Fig. 1). The least bacterial count was detected in 4lacti (Nordfarm) - $10^{4} \mathrm{CFU} /$ dose, Biotyk (Lekam) $-10^{5} \mathrm{CFU} /$ dose and Biopron9 (Valosun) - $10^{7} \mathrm{CFU} /$ dose.

A systemic molecular approach using the Multiplex and single PCR was undertaken to gather direct evidence for the presence of bacteria stated to be present in the probiotic products. In three of them, less species were found than declared. Several strains described on the label by manufacturer were not identified. In Biopron9 (Valosun) out of nine declared bacterial species only two (L. rhamnosus, S. thermophilus) were detected (Table 1). In 4lacti (Nordfarm), two LAB species were found (L. acidophilus and L. casei) when two more were declared (S. thermophilus and B. bifidum). In Asecurin (Aflopharm), out of three lactobacilli species, L. reuteri was undetected (Table 1).

Table 1. Comparison of label claims with and actual viable bacterial count and identification results

\begin{tabular}{|c|c|c|c|c|c|c|}
\hline Product & $\begin{array}{l}\text { Preparation } \\
\text { form }\end{array}$ & $\begin{array}{c}\text { Declared total count } \\
\text { (CFU/dose) }\end{array}$ & Species declared on the label & PCR identification & $\begin{array}{c}\text { Lactobacilli detected } \\
\text { (CFU/dose) }\end{array}$ & $\begin{array}{c}\text { Bifidobacteria and } \\
\text { others detected } \\
\text { (CFU/dose) }\end{array}$ \\
\hline Osłonka Normal (Apotex) & Capsules; DS & $5.0 \times 109$ & $\begin{array}{l}\text { Lactobacillus rhamnosus } \\
\text { Lactobacillus plantarum } \\
\text { Bifidobacterium lactis }\end{array}$ & $\begin{array}{l}\text { L. rhamnosus } \\
\text { L. plantarum } \\
\text { B. lactis }\end{array}$ & $1.8 \times 109$ & $8 \times 108$ \\
\hline Biotyk (Lekam) & Capsules; DS & $1.0 \times 109$ & Lactobacillus casei & L. casei & $7.4 \times 105$ & \\
\hline 4lacti (Nordfarm) & Capsules; DS & $4.0 \times 109$ & $\begin{array}{l}\text { Lactobacillus acidophilus } \\
\text { Bifidobacterium bifidum } \\
\text { Lactobacillus casei subsp. } \\
\text { rhamnosus } \\
\text { Streptococcus thermophilus }\end{array}$ & $\begin{array}{l}\text { L. acidophilus } \\
\text { L. casei }\end{array}$ & $3.8 \times 104$ & \\
\hline Biopron 9 (Valosun) & Capsules; DS & $4.5 \times 109$ & \begin{tabular}{|c|} 
Lactobacillus acidophilus \\
Lactococcus lactis ssp. lactis \\
Bifidobacterium longum \\
Bifidobacterium breve \\
Lactobacillus rhamnosus \\
Streptococcus thermophilus \\
Bifidobacterium bifidum \\
Lactobacillus casei \\
Lactobacillus plantarum \\
\end{tabular} & $\begin{array}{l}\text { L. rhamnosus } \\
\text { S. thermophilus }\end{array}$ & $5.2 \times 106$ & $3.4 \times 107$ \\
\hline Dicoflor (Vitis Pharma) & Capsules FSMP & $6.0 \times 109$ & Lactobacillus rhamnosus & L. rhamnosus & $1.7 \times 109$ & \\
\hline Asecurin (Aflofarm) & Capsules; DS & $6 \times 109$ & $\begin{array}{c}\text { Lactobacillus rhamnosus } \\
\text { Lactobacillus reuteri } \\
\text { Lactobacillus gasseri }\end{array}$ & $\begin{array}{l}\text { L. rhamnosus } \\
\text { L. gasseri }\end{array}$ & $2.2 \times 108$ & \\
\hline Trilac (Krotex) & Capsules FSMP & $1.6 \times 109$ & $\begin{array}{l}\text { Lactobacillus acidophilus } \\
\text { Lactobacillus delbrueckii } \\
\text { subsp. bulgaricus } \\
\text { Lactobacillus rhamnosus } \\
\text { Bifidobacterium lactis } \\
\end{array}$ & $\begin{array}{l}\text { L. acidophilus } \\
\text { L. delbrueckii } \\
\text { L. rhamnosus } \\
\quad \text { B. lactis }\end{array}$ & $4.9 \times 107$ & $6.7 \times 108$ \\
\hline Lacidofil (Merk) & Capsules; MP & $2.0 \times 109$ & $\begin{array}{l}\text { Lactobacillus rhamnosus } \\
\text { Lactobacillus helvetius } \\
\text { (formerly L. acidophilus) }\end{array}$ & $\begin{array}{l}\text { L. rhamnosus } \\
\text { L. acidophilus }\end{array}$ & $1.8 \times 109$ & \\
\hline Lakcid (Biomed) & Powder; MP & $2.0 \times 109$ & $\begin{array}{l}\text { Lactobacillus rhamnosus Pen } \\
\text { Lactobacillus rhamnosus E/N } \\
\text { Lactobacillus rhamnosus Oxy }\end{array}$ & L. rhamnosus & $1,1 \times 109$ & \\
\hline $\begin{array}{l}\text { BioGaia Protectis } \\
\text { (Ewopharma) }\end{array}$ & Tablets ; FSMP & $1.0 \times 108$ & $\begin{array}{c}\text { Lactobacillus reuteri } \\
\text { Protectis }\end{array}$ & L. reuteri & $2.8 \times 108$ & \\
\hline
\end{tabular}

DS - dietary supplement; MP - medicinal product; FSMP - food for special medical purposes; CFU - colony forming unit;s PCR - polymerase chain reaction 


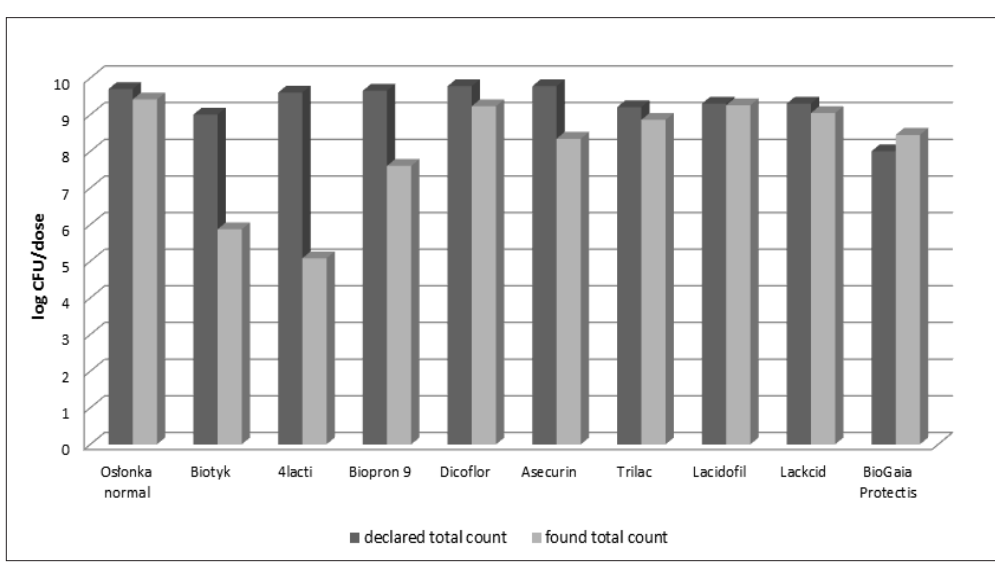

Figure 1. Comparison of viable bacterial counts in probiotic products

applied $[12,14]$. All of species detected in the tested probiotic products were successfully and rapidly identified using multiplex PCR or single species-specific PCR. This indicates that due to the highly sensitive nature of PCR, quick, effective and economical methods can be used for the screening of microbial composition of probiotic products.

Fortunately, in our study, the tested probiotic products were not cross-contaminated by potentially pathogenic strains that can be harmful for patients. Some of the products tested in studies presented elsewhere contained Enterococcus faecium [8,16], Staphylococcus spp [8], Micromonas spp. [17], Bacillus spp. [8,13].

According to Morgan et al. [18], the main

\section{DISCUSSION}

The consumption of probiotic-based products, both as traditional foods and dietary supplements, has increased. However, many studies have demonstrated that probiotic action tend to be strain-specific, and that the amount of ingested viable cells influences the effectiveness, which is why it is important for each product to be correctly labeled and that the identity and viability of each strain is guaranteed [1].

This study was carried out to determine if products available on the Polish market in 2016 were correctly labeled in terms of quantity of viable bacteria, as well as in identification of probiotic species. However, the quality of probiotic products varies and depends on preparation standard, shipping conditions, storage environment and consumer handling. Previous studies provided by Szajewska et al. $[11,12]$ analyzed the bacteria viability of probiotic medicinal products available in Poland. Here, microbiological analysis showed that the quantity of tested products for medicinal purposes in $11-20 \%$ of samples had a lower bacterial count than was claimed $[9,10]$. Furthermore, genetic analysis showed that in terms of quality, only three of five products contained the bacterial strains claimed on the label [12]. Zawistowska-Rojek et al. [7] in their experiment, found that only one medicinal product, two dietary supplements and two FSMP of 125 tested probiotic products available in the Polish market showed a good quality with respect to the bacterial count. Here, in 15 of them, compliance of species with the label was proved [7].

The results of this study confirmed that many products (70\%) available on the market had inappropriate bacterial count or/and less probiotic species than was claimed on their labels. Such a problem was also reported in other European and North American countries [8,13-17]. Many products were labeled with misidentified bacterial strains or even fictitious names. In general, a big mismatch between the detected number of viable bacteria and label statement was revealed.

Traditional microbiological methods for identification of isolates are time-consuming and show the disadvantages of low selectivity. To achieve a rapid and reliable identification of species, molecular methods such as species-specific PCR, multiplex PCR, denaturing gradient gel electrophoresis PCR or genetic fingerprinting have been increasingly issues regarding the viability of microorganisms in commercial products were processing, packaging and storage. Storing the product at $4^{\circ} \mathrm{C}$ is sufficient to maintain its viability. This statement was suggested on the label of one of the products tested in our study for medicinal products (Lacidofil and Lakcid). These products also demonstrated in our study the appropriate number of viable bacterial cells.

\section{CONCLUSIONS}

This study confirmed that probiotic products are often of poor quality. Only some, including medicinal products, meet the standard of being probiotics containing viable, defined probiotic bacteria in adequate amounts to confer health benefits to a host. Of note, Probiotics sold as dietary supplements and FSMP tend to be lower quality than medicinal products. Our resultt provide supportine evidence that, for the patients' sake, the need for regulatios concerning truthfue labeling of probiotic products is evidene. Moreovers improved persistent monitoring of their microbiological quality is needed.

\section{ORCID iDs}

Izabela Korona-Głowniak

(Dhttps://orcid.org/0000-0003-1634-0387

\section{REFERENCES}

1. Report WHO/FAO. Probiotics in food: Health and nutritional properties and guidelines for evaluation. Rome 2006. Food and Agriculture Organization of the United Nations: 1-29.

2. Hove $\mathrm{H}$, Nørgaard $\mathrm{H}$, Mortensen PB. Lactic acid bacteria and the human gastrointestinal tract. Eur J Clin Nutr. 1999;53:339-50.

3. Szajewska H, Mrukowicz JZ. Probiotics in the treatment and prevention of acute infectious diarrhea in infants and children: a systematic review of published randomized, double-blind, placebocontrolled trials. J Pediatr Gastroenterol Nutr. 2001;33(Suppl 2): S17-25.

4. Chapman CM, Gibson GR, Rowland I. Health benefits of probiotics: are mixtures more effective than single strains? Eur J Nutr. 2011; 50:1-17.

5. Pereira DI, McCartney AL, Gibson GR. An in vitro study of the probiotic potential of a bile-salt-hydrolyzing Lactobacillus fermentum strain, and determination of its cholesterol-lowering properties. Appl Environ Microbiol. 2003;69:4743-52.

6. Lu L, Walker WA. Pathologic and physiologic interactions of bacteria with gastrointestinal epithelium. Am J Clin Nutr. 2001;3:1124-1130S. 
7. Zawistowska-Rojek A, Zaręba T, Mrówka A, Tyski S. Assessment of the microbiological status of probiotic products. Pol J Microbiol. 2016;65:97-104.

8. Drago L, Rodighiero V, Celeste T, Rovetto L, De Vecchi E. Microbiological evaluation of commercial probiotic products available in the USA in 2009. J Chemother. 2010;22:373-7.

9. Song Y, Kato N, Liu C, Matsumiya Y, Kato H, Watanabe K. Rapid identification of 11 human intestinal Lactobacillus species by multiplex PCR assays using group- and species-specific primers derived from the 16S-23S rRNA intergenic spacer region and its flanking 23S rRNA. FEMS Microbiology Letters. 2000;187:167-73.

10. Motevaseli E, Shirzad M, Raoofian R, Hasheminasab SM, Hatami M, Dianatpour M et al. Differences in vaginal lactobacilli composition of iranian healthy and bacterial vaginosis infected women. Iranian Red Crescent Medical Journal. 2013;15:199-206.

11. Szajewska H, Fordymacka A, Banaszkiewicz A. Microbiological qualitative and quantitative analysis of probiotic products registered in Poland for medicinal purposes (pilot study). Pediatria Polska 2002; LXXVII: 941-4.

12. Szajewska H, Fordymacka A, Bardowski J, Górecki RK, Mrukowicz JZ, Banaszkiewicz A. Microbiological and genetic analysis of probiotic products licensed for medicinal purposes. Med Sci Monit 2004;10:346-50.
13. Aureli P, Fiore A, Scalfaro C, Casale M, Franciosa G. National survey outcomes on commercial probiotic food supplements in Italy. Int J Food Microbiol. 2010;137:265-7.

14. Drisko J, Bischoff B, Giles C, Adelson M, Rao RV, McCallum R. Evaluation of five probiotic products for label claims by DNA extraction and polymerase chain reaction analysis. Dig Dis Sci. 2005;50:1113-7.

15. Huys G, Vancanneyt M, D'Haene K, Vankerckhoven V, Goossens H, Swings J. Accuracy of species identity of commercial bacterial cultures intended for probiotic or nutritional use. Res Microbiol. 2006;157:803-10.

16. Weese JS. Evaluation of deficiencies in labeling of commercial probiotics. Can Vet J. 2003;44:982-3.

17. Milazzo I, Speciale A, Musumeci R, Fazio D, Blandino G. Identification and antibiotic susceptibility of bacterial isolates from probiotic products available in Italy. New Microbiol. 2006;29:281-91.

18. Morgan CA, Herman N, White PA, Vesey G. Preservation of microorganisms by drying; a review. J Microbiol Methods. 2006;66:183-93. 